\title{
Effect of Cell-Phone Assisted Postpartum Counseling on the Use Of Long-Acting Reversible Contraceptives: A Randomized Controlled Trial
}

\author{
Treza S. Badia ${ }^{1}$, Manal F. Moustafa ${ }^{2}$, Omar M. Shaaban $^{3}$ \& Entisar M. Youness ${ }^{4}$. \\ 1. Assistant Lecturer of Maternity and Newborn Health Nursing, Faculty of Nursing, Assuit University, Egypt. \\ 2. Professor of Maternity and Newborn Health Nursing, Faculty of Nursing, Assuit University, Egypt. \\ 3. Professor of Obstetrics \& Gynecology, Faculty of Medicine, Assuit University, Egypt. \\ 4. Professor of Maternity and Newborn Health Nursing, Faculty of Nursing, Assuit University, Egypt.
}

\begin{abstract}
Aim of the study: To assess the effect of adding cell-phone to the postpartum family planning counseling and service on the intake of postpartum women to LARC and the overall contraceptive performance. Subjects and Methods: Open labeled Randomized controlled Trial design was used in this study, the sample comprised 864 women that divided into two main groups, 432 for each group, Study and control groups. Results:: Show that during the 1st visit postpartum (40 days) women's attending FP clinic was significantly higher in the cell phone assisted group as compared to control group $67.8 \%$ versus $38.3 \%$;respectively ( $\Rightarrow>0.001$ ). Conclusion: The current study showed that adding cell-phone to the postpartum family planning counseling and service can improve the intake of postpartum women to LARC and the overall contraceptive performance and consequently decrease incidence of unplanned pregnancy. Recommendation: it is necessity to create and increase awareness about long acting contraceptive methods and adding phone calls as a reminder to women for improvement uptake of LARC and the overall contraceptive performance.
\end{abstract}

\section{Key words: Cell phone, Counseling, Postpartum, LARC \& Contraception.}

\section{Introduction}

The most recent Egyptian Demographic Health Survey (EDHS, 2014) evidenced that the total fertility rate (TFR) in Egypt start to rise again after substantial decline achieved up to 2008. TFR rose between the 2008 and 2014 Egypt DHS surveys by17 $\%$, from 3.0 births to 3.5 births. The 2014 TFR still at the same level as the TFR showed in the 2000 EDHS. (Edhs, 2014)

Increase in the fertility observed in the EDHS results is also apparent in the statistics on births since 2008 notified in Egypt's civil recording. Based on the birth enrollment data, the Central Agency for Public Mobilization and Statistics rated that the rate of crude birth increased from 27.3 births per 1,000 populations in 2008 to 31.9 births in 2012, a $17 \%$ increase

(Capms,2013).

Unplanned and closely spaced pregnancies are a main public health problem that effects on both the individuals involved directly and the society indirectly. It raises the risks of newborn with undesirable outcomes like preterm, low weight at birth and small for age of gestation. Pregnancy that occurs within six months of the latest delivery holds a 7.5 fold raise induced abortion risk, and a 1.6-fold raise stillbirth risk. But, use of contraceptive methods has been shown to decrease unintended pregnancy, rates of high fertility and maternal mortality (DaVanzo et al., 2007).
In addition to, the most effective reversible contraceptives, long acting reversible contraceptive (LARC) methods have other advantages as long acting; where they can be used for 10 years also don't need regular maintenance. (O'Shea et al., 2015).

Methods of LARC used in the US still lower than minimal effective methods like oral contraceptive pills or barrier methods as condoms. SO, same day placement of IUD and implant protocols was advised to decrease barriers to use and ensure that immediate insertion after delivery, abortion, and post miscarriage is safe, suitable, and necessary to decrease delays. (Acog, 2012)

For improving postpartum contraceptive use, one potentially useful approach is using the great available cellular phone which nearly was handling with all couples in experiment to increase attendance of women, initiation and correct use of birth spacing methods particularly long acting reversible contraceptives. There is a great potential that this way can direct and remind women towards their needs of contraceptive methods. (Wilson, 2011)

The role of nurse in family planning has taken on new depth in recent years. The nurse has become involved in all levels of family planning. As initial contact in the family planning clinic, the nurse can encourage a positive attitude toward family planning, evaluate the patient's knowledge, lead group discussions facilitate communication and answer questions, prepare the client for examination, and clarify the instructions for new patient. Of crucial

Vol , (7) No , (17) June, 2019 
importance is follow-up, including home visits and a "hot-line" to relieve anxieties of new contraceptive patients. Medical or emotional problems in new patients failing to return to the clinic can be managed through the role of the nurse in follow-up (Winn et al., 2016)

The nurse must also maintain a professional attitude when her own religious or social concerns conflict with those of the patient. The Demographic and Health Surveys and other research studies have identified side effects and perceived health problems as the major reasons clients give for stopping FP use; and fear of these effects is major reason for not adopting modern methods in the first place (Tomlin et al., 2016).

\section{Significant of the study}

Egypt, currently suffers from a drop in contraceptive use specially LARC methods and high incidence of unplanned pregnancy during postpartum period. Up to the knowledge of the investigators, there were no specific studies conducted to assess impact of cellphone assisted postpartum family planning counseling on the use and performance of postpartum contraceptive use in Egypt. Hence, we are conducting this study to assess the contraceptive intake (especially LARC), correct use, pregnancy rate during postpartum period and percentage of unplanned pregnancy. With the wide availability of the cell phone in the hand of every woman or every family, we also suggest that adding cell-phone assistance to postpartum family planning counseling may improve the initiation and performance of LARC use in Egypt.

\section{The Aim of the Study}

Was to assess the effect of adding cell-phone to the postpartum family planning counseling and service on the intake of postpartum women to LARC and the overall contraceptive performance.

\section{Research hypothesis}

Adding cell-phone to the postpartum family planning counseling and service was expected to enhance the intake of postpartum women to LARC and the overall contraceptive utilization.

\section{Subject \& Methods \\ Research design}

Open Labeled Randomized Controlled Trial design was used in this study.

\section{Setting}

This study was conducted in the postpartum ward and the Outpatient Family Planning Clinic of Woman's Health Hospital, Assiut University Hospitals, Egypt, during the period from the first of May 2017 to the end of April 2018.

\section{Subjects}

All women delivered in the obstetric department during study period were approached to participate.

Inclusion criteria

- Women who deliver a live birth at greater than 28 week's gestation.

- Women desire birth spacing for more than one year

- Women who were holding and /or one of her family hold a cell-phone and accept to receive messages and phone calls to remind her with her contraceptive program

Exclusion criteria

- Women who refuse to participate in the study.

- Women aren't able to respond to the questionnaire due to their health status.

- Anticipation of difficulty of subsequent communication with the women

- Women with contraindications of using LARC

\section{Sample size}

Sample size calculation was based on the primary outcome (Initiation of LARC within the first 6 months postpartum). Previous study which was done by Shaaban and Galsier in 2008 reported initiation rate of LARC uptake (IUD and Implants) in the first 6 months postpartum was in $23.9 \%$ of women.

Presumed that the cell-phone assistance of postpartum family planning counseling can increase the initiation of LARC by $10 \%$ to $33.9 \%$. Using two sided chi-square $(\chi 2)$ test with $\alpha$ of 0.05 , a minimum sample size of at least 864 in the 2 groups (taking a ratio of 1:1 unexposed to exposed), this gave 432 women in each group, using $90 \%$ power to detect $10.0 \%$ difference between the 2 groups. [odds ratio of 1.633] (Epi-info $\left.{ }^{\mathrm{TM}}, \mathrm{CDC}, \mathrm{USA}, 2017\right)$.

There were 86 women lost follow up in the $1^{\text {st }}$ visit (40 days postpartum), thirty nine women in group A and 47women in group B. However in the second follow up (6 months postpartum) there were 64 women lost, twenty nine women in group A and 35 women in group B. the researcher added number of women that lost during the follow up to the total number of study and control group, so number of cases in study group become 500 cases $(432+68$ lost) and the total number of control group become 514 cases $(432+82$ lost) figure (1).

\section{Randomization}

Randomization was done by using computergenerated random table. After acceptance of eligible women to participate in the study, they were assigned randomly to either one of the above groups. Allocation concealment was done using serially numbered closed opaque envelope. Once allocation had been done, it couldn't be changed.

Tools of the study

The following tool was used in the current study 
- A Structured interviewing questionnaire which included the following data:

- Part (A) Personal data: such as name, age, occupation, address, date of admission, educational level, residence, date of admission, duration of marriage.

- Part (B) Obstetric history: gravidity, parity, number of living children, and number of abortion.

- Part (C) History of using the family planning methods type of previous contraceptive method used, duration of use, complications while using, and cause of termination.

- Part (D) Current labour data: the date and mode of delivery \& presence of any complications during labour.

- Part (E) previous knowledge about LARC: woman was asked if she heard about long acting reversible contraceptive methods, its safety, efficacy and period of efficacy.

- Follow up sheet:

Every woman was followed at the $6^{\text {th }}$ week $\&$ at the end of the $6^{\text {th }}$ month postpartum to answer the following questions during her visit to outpatient family planning clinic or by a phone call:

- Had she attended any family planning service or not?

- If yes, she was asked to identify where she attended.

- Had she initiated using any method of contraception or not?

- Had she initiated using LARC methods or not?

- If yes, she was asked to identify the type of this method \& date of initiation.

- Also asking about period of continuation.

- If she got pregnant during this period or not?

- Recounseling women if needed.

\section{Procedure}

The main procedure for data collection was through personal and single face-to face interview with every woman. Before conducting the study, an exploratory visit was done in postpartum ward \&family planning clinic in order to identify the suitable time for collecting data according to each unit.

Besides, personal communication was done with nurses and physician to explain the purpose of the study and gain their best possible cooperation.

Women who met the study criteria were included in the study after explaining the purpose of the study and obtaining oral consent. The data was collected through five days per week; three rooms for each group, time taking for every case was 20 minutes. The full history was taken as it was in the structured questionnaire which included information for Sociodemographic data, reproductive history (e.g. Pregnancy, parity, abortions, number of living birth) $\&$ history of contraceptives using. Every question was addressed to the case and the responses were recorded.

All women of both groups were counseled for importance of postpartum family planning and its different options before hospital discharge especially LARC including knowledge about methods as safety, efficacy, advantages, side effects, possible complications and duration of use; every woman were given booklet containing comprehensive knowledge about family planning methods.

Group A: Cell-phone assisted (study group) were advised that they were going to receive a reminder of their postpartum family planning visit as the following:

- A phone call at $5^{\text {th }}$ week after the delivery (one week before the scheduled visit)

- A phone call 48 hours before the scheduled visit.

- They also received two follow-up phone calls to answer any quires and to remind them with the follow-up visits after method initiation.

Women were given a referral card by the researcher to the outpatients' family planning clinic denoting her study group, serial number and with a specific date for postpartum family planning visits. They were also provided with a cell phone number working 7 days a week from $8 \mathrm{AM}$ to $8 \mathrm{PM}$ to answer any questions regarding her family planning program.

Group B: the control group received the same above adequate counseling with referral card to the outpatients' family planning clinic denoting her control group, serial number and with a specific date for postpartum family planning visits. They were also provided with a cell phone number working 7 days a week from $8 \mathrm{AM}$ to $8 \mathrm{PM}$ to answer any questions regarding her family planning program.

\section{Follow-up}

Every woman of both groups were followed at the end of $6^{\text {th }}$ month postpartum to answer the questions, which were in the follow up sheet during her visit to outpatient family planning clinic or, by a phone interview.

Pilot study

After preparation of the questionnaire, it was pretested on $10 \%$ of the study sample (85) patients before the beginning of data collection to test the relevance of the questions to the aim of the work and to determine whether they were understood by the respondents or not. The pilot study sample was included in the main study.

\section{Statistical Analysis}

The data were tested for normality using the Anderson-Darling test and for homogeneity variances prior to further statistical analysis. Categorical variables were described by number \& percent $(\mathrm{N}$, $\%)$, where continuous variables described by mean

Vol , (7) No, (17) June, 2019 
and standard deviation (Mean, SD). Chi-square test was used to compare between categorical variables where compare between continuous variables by unpaired t-test. A two-tailed $\mathbf{p}<0.05$ was considered statistically significant. All analyses were performed with the IBM SPSS 20.0 software.

\section{Ethical consideration}

1. Research proposal would be approved from Ethical Committee in the Faculty of Nursing

2. There was no risk for study subject during application of the research.

3. The study followed common ethical principles in clinical research

4. Oral consent was obtained from patient or guidance that is willing to participate in the study

5. Confidentiality and anonymity was assured.

6. Study subjects had the right to refuse to participate and /or to withdraw from the study without any rational any time.

7. Study subject privacy were considered during collection of data. 


\section{Results}

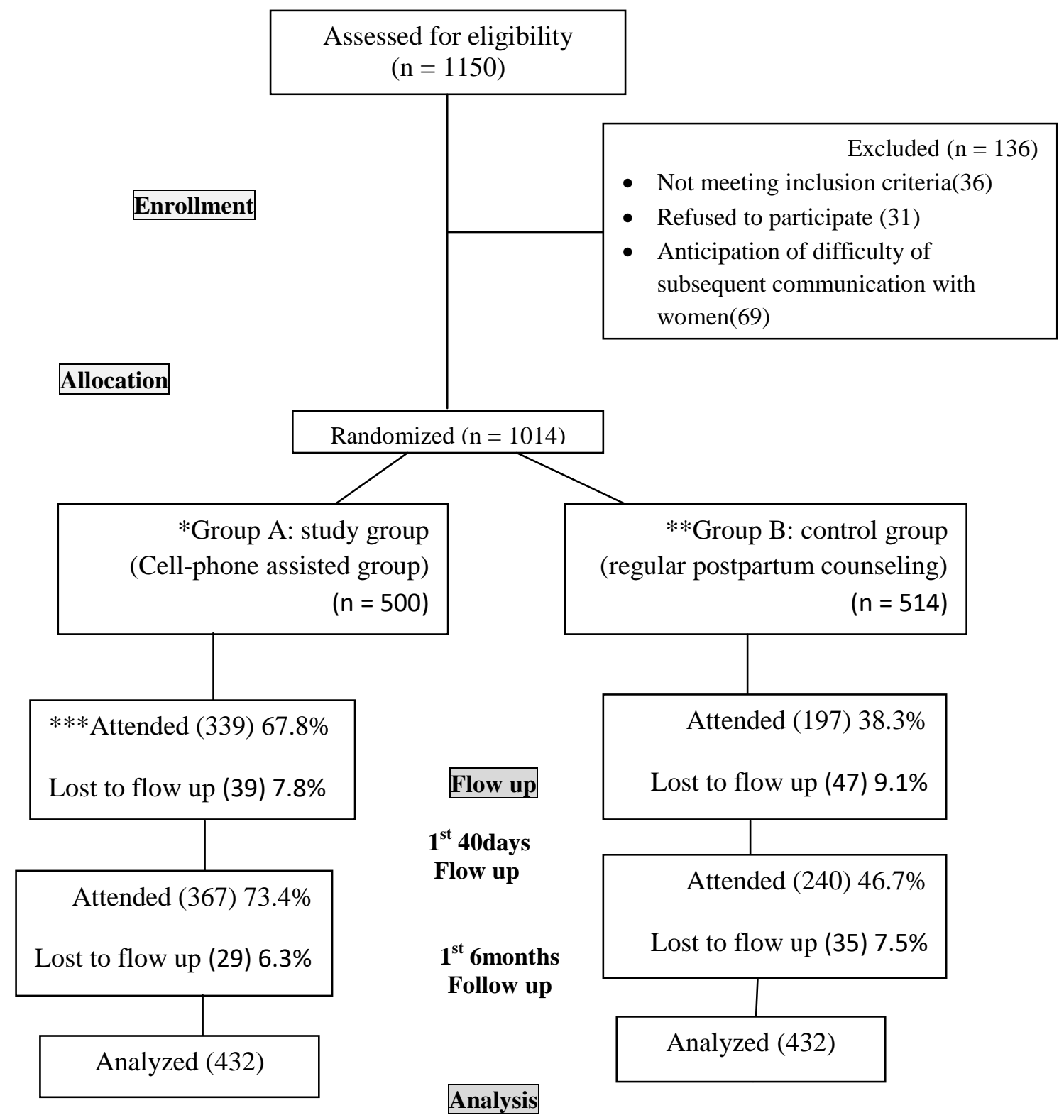

Figure (1): Study flow chart.

*Group A: study group (Cell-phone assisted postpartum family planning counseling group)

**Group B: control group (regular postpartum family planning counseling group)

***Attended means attending any family planning unite ether our facility or any other facility

Figure (1): We recruited 1150 women to participate in the study (figure 1). One hundred and thirty six women were excluded. We randomly assigned 1014 women into both groups A \& B. Five hundred women in study group (group A), five hundred and fourteen women in control group (group B). There were 86women lost follow up in the $1^{\text {st }}$ visit (40 days postpartum), thirty nine women in group A and 47 women in group B. However in the second follow up (6 months postpartum) there were 64 women lost, twenty nine women in group A and 35 women in group B. Eight hundred and sixty four women were analyzed 432 women in each group. 
Table (1): Distribution of women according to personal data in study and control groups

\begin{tabular}{|c|c|c|c|c|c|}
\hline \multirow[t]{2}{*}{ Variables } & \multicolumn{2}{|c|}{$\begin{array}{c}\text { Group(A) } \\
\text { Study }(n=500)\end{array}$} & \multicolumn{2}{|c|}{$\begin{array}{c}\text { Group }(B) \\
\text { Control }(n=514)\end{array}$} & \multirow[t]{2}{*}{ P. value } \\
\hline & No. & $\%$ & No. & $\%$ & \\
\hline Age mean \pm SD & \multicolumn{2}{|c|}{$27.92 \pm 5.852$} & \multicolumn{2}{|c|}{$27.38 \pm 5.956$} & \\
\hline$<20$ years & 44 & 8.8 & 64 & 12.5 & \multirow{3}{*}{0.122} \\
\hline $20-30$ years & 281 & 56.2 & 289 & 56.2 & \\
\hline$>30$ years & 175 & 35.0 & 161 & 31.3 & \\
\hline Working outside household & 18 & 3.6 & 19 & 3.7 & 0.935 \\
\hline \multicolumn{6}{|l|}{ Education level } \\
\hline Illiterate & 123 & 24.6 & 121 & 23.5 & \multirow{6}{*}{0.919} \\
\hline Read \&write & 45 & 9.0 & 52 & 10.1 & \\
\hline Primary & 40 & 8.0 & 45 & 8.8 & \\
\hline Preparatory & 83 & 16.6 & 77 & 15.0 & \\
\hline Secondary & 158 & 31.6 & 171 & 33.3 & \\
\hline University & 51 & 10.2 & 48 & 9.3 & \\
\hline \multicolumn{6}{|l|}{ Residence } \\
\hline Rural & 396 & 79.2 & 403 & 78.4 & \multirow{3}{*}{0.109} \\
\hline Urban & 36 & 7.2 & 54 & 10.5 & \\
\hline Semi Urban & 68 & 13.6 & 57 & 11.1 & \\
\hline
\end{tabular}

Group $(A):$ Study group= Cell-phone assisted postpartum family planning counseling group

Group $(B)$ Control group= regular postpartum family planning counseling group

Table (2): Distribution of women according to obstetric history in study and control groups.

\begin{tabular}{|c|c|c|c|c|c|}
\hline \multirow[t]{2}{*}{ Variables } & \multicolumn{2}{|c|}{$\begin{array}{c}\text { Group(A) } \\
\text { Study }(n=500)\end{array}$} & \multicolumn{2}{|c|}{$\begin{array}{c}\text { Group }(B) \\
\text { Control }(n=514)\end{array}$} & \multirow[t]{2}{*}{ P. value } \\
\hline & No. & $\%$ & No. & $\%$ & \\
\hline \multicolumn{5}{|l|}{ Type of delivery } & \multirow{3}{*}{0.160} \\
\hline Normal & \multicolumn{2}{|c|}{117} & \multicolumn{2}{|c|}{23.4} & \\
\hline $\mathrm{CS}$ & \multicolumn{2}{|c|}{383} & \multicolumn{2}{|c|}{76.6} & \\
\hline Gravidity mean \pm SD & \multicolumn{2}{|c|}{$3.02 \pm 1.334$} & \multicolumn{2}{|c|}{$3.04 \pm 1.372$} & \\
\hline None & 86 & 17.2 & 102 & 19.8 & \multirow{5}{*}{0.751} \\
\hline 1 & 85 & 17.0 & 89 & 17.3 & \\
\hline 2 & 97 & 19.4 & 104 & 20.2 & \\
\hline $3-5$ & 125 & 25.0 & 120 & 23.3 & \\
\hline$>5$ & 107 & 21.4 & 99 & 19.3 & \\
\hline Parity mean \pm SD & \multicolumn{2}{|c|}{$2.96 \pm 1.392$} & \multicolumn{2}{|c|}{$2.91 \pm 1.455$} & \\
\hline None & 103 & 20.6 & 112 & 21.8 & \multirow{5}{*}{0.415} \\
\hline 1 & 93 & 18.6 & 118 & 23.0 & \\
\hline 2 & 112 & 23.4 & 101 & 19.6 & \\
\hline $3-5$ & 120 & 24.0 & 114 & 22.2 & \\
\hline$>5$ & 72 & 14.4 & 69 & 13.4 & \\
\hline History of abortion mean \pm SD & \multicolumn{2}{|c|}{$1.57 \pm 0.811$} & \multicolumn{2}{|c|}{$1.56 \pm 0.778$} & \\
\hline None & 293 & 58.6 & 297 & 57.8 & \multirow{4}{*}{0.857} \\
\hline$<3$ & 150 & 30.0 & 163 & 31.7 & \\
\hline $3-5$ & 34 & 6.8 & 35 & 6.8 & \\
\hline$>5$ & 23 & 4.6 & 19 & 3.7 & \\
\hline Number of living children mean \pm SD & \multicolumn{2}{|c|}{$2.31 \pm 0.958$} & \multicolumn{2}{|c|}{$2.26 \pm 0.956$} & \multirow{5}{*}{0.620} \\
\hline None & 110 & 22.0 & 118 & 23.0 & \\
\hline$<3$ & 193 & 38.6 & 212 & 41.2 & \\
\hline $3-5$ & 131 & 26.2 & 117 & 22.8 & \\
\hline$>5$ & 66 & 13.2 & 67 & 13.0 & \\
\hline
\end{tabular}

Group (A): Study group= Cell-phone assisted postpartum family planning counseling group

Group $(B)$ Control group = regular postpartum family planning counseling group

Vol , (7) No, (17) June, 2019 
Table (3): Distribution of women according to family planning history in study and control groups.

\begin{tabular}{|l|c|c|c|c|c|}
\hline \multirow{2}{*}{\multicolumn{1}{c}{ Variables }} & \multicolumn{2}{c|}{$\begin{array}{c}\text { Group(A) } \\
\text { Study (n=500) }\end{array}$} & \multicolumn{2}{c|}{$\begin{array}{c}\text { Group(B) } \\
\text { Control(n=514) }\end{array}$} & \multirow{2}{*}{ P. value } \\
\cline { 2 - 6 } & No. & \% & No. & \% & \\
\hline Ever use of Family planning method & 316 & 63.2 & 318 & 61.9 & 0.661 \\
\hline *Type of contraceptive history & & & & & \\
\hline Pills & 186 & 56.4 & 174 & 52.4 & 0.307 \\
\hline IUD & 113 & 34.0 & 116 & 34.9 & 0.850 \\
\hline Injection & 82 & 24.8 & 74 & 22.3 & 0.438 \\
\hline Breast feeding & 79 & 23.9 & 76 & 22.9 & 0.750 \\
\hline Implant & 33 & 10.0 & 39 & 11.7 & 0.470 \\
\hline
\end{tabular}

Group(A): Study group = Cell-phone assisted postpartum family planning counseling group

Group $(B)$ Control group = regular postpartum family planning counseling group

IUD=intrauterine device

*: Each lady may had used more than one method

Table (4): Knowledge of women about LARC during postpartum contraceptive counseling.

\begin{tabular}{|c|c|c|c|c|c|}
\hline \multirow[t]{2}{*}{ Variables } & \multicolumn{2}{|c|}{$\begin{array}{c}\operatorname{Group}(A) \\
\text { Study }(n=500)\end{array}$} & \multicolumn{2}{|c|}{$\begin{array}{c}\text { Group(B) } \\
\text { Control }(n=514) \\
\end{array}$} & \multirow{2}{*}{$\begin{array}{c}\operatorname{Group}(B) \\
\text { Control }(n=514)\end{array}$} \\
\hline & No. & $\%$ & No. & $\%$ & \\
\hline Ever heard about LARC before & 244 & 48.8 & 245 & 47.7 & 0.718 \\
\hline \multicolumn{5}{|l|}{ LARC methods } & \multirow{3}{*}{0.478} \\
\hline IUD & 28 & 11.5 & 34 & 13.9 & \\
\hline Implant & 114 & 46.7 & 102 & 41.6 & \\
\hline IUD \& implant & 102 & 41.8 & 109 & 44.5 & \\
\hline Believed that this method is safe & 166 & 68.0 & 163 & 66.5 & 0.723 \\
\hline Believed that this method is effective & 165 & 67.6 & 154 & 62.9 & 0.269 \\
\hline \multicolumn{5}{|l|}{ Duration of IUD effectiveness } & \multirow{6}{*}{0.694} \\
\hline One year & 8 & 4.8 & 13 & 8.4 & \\
\hline Five years & 37 & 22.4 & 38 & 24.7 & \\
\hline Ten years & 80 & 48.5 & 71 & 46.1 & \\
\hline More than ten years & 21 & 12.7 & 15 & 9.7 & \\
\hline I don't know & 19 & 11.5 & 17 & 11.0 & \\
\hline \multicolumn{5}{|l|}{ Duration of Implant effectiveness } & \multirow{6}{*}{0.451} \\
\hline One year & 12 & 7.3 & 13 & 8.4 & \\
\hline Two years & 17 & 10.3 & 26 & 16.9 & \\
\hline Three years & 75 & 45.5 & 62 & 40.3 & \\
\hline More than three & 13 & 7.9 & 9 & 5.8 & \\
\hline I don't know & 48 & 29.1 & 44 & 28.6 & \\
\hline
\end{tabular}

Group(A): Study group= Cell-phone assisted postpartum family planning counseling group

Group $(B)$ Control group = regular postpartum family planning counseling group

IUD=intrauterine device

$L A R C=$ long acting reversible contraceptive 
Table (5): Initiation of LARC and other contraceptive methods among study and control groups during the first visit (first 40 days postpartum).

\begin{tabular}{|c|c|c|c|c|c|}
\hline \multirow[t]{2}{*}{ Variables } & \multicolumn{2}{|c|}{$\begin{array}{c}\operatorname{Group}(A) \\
\text { Study }(n=500)\end{array}$} & \multicolumn{2}{|c|}{$\begin{array}{c}\operatorname{Group}(B) \\
\operatorname{Control}(n=514)\end{array}$} & \multirow[t]{2}{*}{ P. value } \\
\hline & No. & $\%$ & No. & $\%$ & \\
\hline Attended FP clinic & 339 & 67.8 & 197 & 38.3 & \multirow{3}{*}{$<0.001 *$} \\
\hline Not attended any FP clinic & 122 & 24.4 & 270 & 52.5 & \\
\hline Lost follow up & 39 & 7.8 & 47 & 9.1 & \\
\hline Started FP method & 331 & 66.2 & 188 & 36.6 & $<0.001 *$ \\
\hline Started LARC method & 152 & 30.4 & 22 & 4.2 & $<0.001^{*}$ \\
\hline \multicolumn{6}{|l|}{ Type of LARC method started } \\
\hline Implant & 38 & 25.0 & 6 & 27.3 & \multirow{2}{*}{0.819} \\
\hline IUD & 114 & 75.0 & 16 & 72.7 & \\
\hline Started other method & 179 & 35.8 & 166 & 32.3 & 0.094 \\
\hline Pills & 125 & 69.8 & 113 & 67.5 & \multirow{2}{*}{0.636} \\
\hline Injection & 54 & 30.2 & 53 & 32.5 & \\
\hline \multicolumn{5}{|l|}{ Reasons of no LARC use } & \multirow{3}{*}{0.578} \\
\hline Not available & 9 & 22.0 & 7 & 28.0 & \\
\hline No satisfaction in previous use & 32 & 78.0 & 18 & 72.0 & \\
\hline \multicolumn{5}{|l|}{ Another reasons } & \multirow{3}{*}{$0.022 *$} \\
\hline Satisfaction for another method & 119 & 86.2 & 133 & 94.3 & \\
\hline Refuse of health care provider & 19 & 13.8 & 8 & 5.7 & \\
\hline
\end{tabular}

Group(A): Study group= Cell-phone assisted postpartum family planning counseling group

Group $(B)$ Control group = regular postpartum family planning counseling group

*=statistical significant difference

$F P=$ family planning

IUD=intrauterine device

$L A R C=$ long acting reversible contraceptive

Table (6): Overall family planning use among study and control groups at the end of follow up:

\begin{tabular}{|c|c|c|c|c|c|}
\hline \multirow[t]{2}{*}{ Variables } & \multicolumn{2}{|c|}{$\begin{array}{c}\operatorname{Group}(\mathbf{A}) \\
\text { Study }(\mathbf{n}=\mathbf{5 0 0})\end{array}$} & \multicolumn{2}{|c|}{$\begin{array}{c}\text { Group }(B) \\
\text { Control }(n=514)\end{array}$} & \multirow[t]{2}{*}{ P. value } \\
\hline & No. & $\%$ & No. & $\%$ & \\
\hline All initiation of FP methods & 367 & 73.4 & 240 & 46.7 & $<0.001 *$ \\
\hline \multicolumn{5}{|l|}{ Time of initiation } & \multirow{5}{*}{$<0.001 *$} \\
\hline Started 2 months & 309 & 61.8 & 180 & 35.0 & \\
\hline Started up to 6 months & 58 & 11.6 & 60 & 11.7 & \\
\hline Not started & 65 & 13.0 & 192 & 37.4 & \\
\hline Lost & 68 & 13.6 & 82 & 16.0 & \\
\hline \multicolumn{5}{|l|}{ Place of initiation } & \multirow{5}{*}{$<0.001 *$} \\
\hline Woman health hospital & 45 & 12.3 & 38 & 15.8 & \\
\hline Hospital of Ministry health & 134 & 36.5 & 109 & 45.4 & \\
\hline $\mathrm{MCH}$ & 163 & 44.4 & 93 & 38.8 & \\
\hline Special clinic & 25 & 6.8 & 0 & 0.0 & \\
\hline Stilling use at 6 month postpartum & 349 & 95.1 & 199 & 82.9 & $<0.001 *$ \\
\hline Desired Pregnancy & 1 & 0.2 & 2 & 0.4 & \multirow{2}{*}{$0.009 *$} \\
\hline Unintended pregnancy & 0 & 0.0 & 10 & 1.9 & \\
\hline
\end{tabular}

Group (A): Study group= Cell-phone assisted postpartum family planning counseling group

Group $(B)$ Control group = regular postpartum family planning counseling group

*=statistical significant difference

$F P=$ family planning

MCH=Maternal \& child health 
Table (1): Shows that there was no statistically significant difference between study and control groups as regards age, working outside household, educational level, residence and marriage period. The mean age of study participant was around 27 years old. Most of our study participants were housewives (96\%).

Table (2): Shows that there was no statistically significant difference between study and control groups as regards gravidity, parity, abortion and number of living children. Within the study group the mean gravidity was $3.02 \pm 1.334$ (range $1->5$ ) compared to $3.04 \pm 1.372$ (range $1->5$ ) in the control group and the mean number of living children in the study and control women were $2.31 \pm 0.958$ (range0$>5$ ), $2.26 \pm 0.956$ (range $0->5$ ) respectively.

Table (3): Shows that there was no statistically significant difference between study and control groups as regards use of family planning methods and the type of previously used contraceptives. In study group $63.2 \%$ of women had used family planning method versus $61.9 \%$ of the control group.

(Table 4): Shows that about $50.0 \%$ of our population ever heard about LARC. About $70.0 \%$ of them believe that the methods were safe \& effective; however women had different knowledge about duration of efficacy of each method.

Table (5): Show that during the $1^{\text {st }}$ visit postpartum (40 days) women's attending FP clinic was significantly higher in the cell phone assisted group as compared to control group $67.8 \%$ versus $38.3 \%$ ;respectively ( $\mathrm{p}=<0.001)$.

(Table 6): Seventy three per cent of our study group had started a reliable contraceptive method within 6 months after delivery compared to $46 \%$ in the control group ( $p=<0.001)$. There was significant higher rate of starting FP method in the first 2 months postpartum in the study compared to the control group $61.8 \%, 35 \%$; respectively.

\section{Discussion}

Effective family planning could prevent as many as one in every three maternal deaths globally by delaying motherhood, spacing births, avoiding unintended pregnancies and abortions, and allowing women to stop childbearing when they have reached their desired family size(Birgisson et al., 2015).

Long-acting reversible contraceptive methods (LARC) like the IUD and implants are not dependent on users' adherence. Additionally, continuation does not require repeated contact with health care providers. These two factors make LARC methods more effective than short-acting methods in preventing pregnancies among typical users (Heffron et al., 2012).
One potentially useful approach for improving contraceptive use is making follow-up phone calls to females after their clinic appointments for contraceptives. Telephone-administered interventions constitute a potentially cost-effective and confidential way to reach individuals who cannot or may not be willing to return to a clinic on a regular basis (Kirby et al., 2010)

The aim of the present study was to assess the effect of adding cell-phone to the postpartum family planning counseling and service on the intake of postpartum women to LARC and the overall contraceptive performance.

Regarding personal data of the participants, the mean age was around 27 years old. This finding is agree with (Crede et al., 2012) who reported that the participants were most commonly in the twenty five years old, with median age 27. According to status of education, about one third of our populations were secondary level with no significant difference among women of both groups. This finding is agree with (Shaaban et al., 2013) in their study to assess the effect of using LAM+EC versus using LAM only on the use of FP methods, found that almost half of women in the sample had secondary level.

Nearly two third of women in the present study, had used contraceptive before, more than half of them had used oral contraceptive pills, about one third for IUD, one quarter for each Depo Provera (DMPA) \& LAM methods, only $10 \%$ for implant method. This finding agrees with EDHS 2014, there was $59 \%$ of currently Egyptian married women are using contraception.

When exploration the knowledge of women about LARC methods, its effectiveness \& its safety, about half of our population ever heard about LARC. Two thirds of them believe that the methods were safe \& effective. Few number of them said that IUD was LARC methods and about half of them said it was implant. This finding agree with (Alemayehu et al., 2012) who assessed factors which affected using of long acting reversible contraceptive methods between married women at reproductive age in north Ethiopia, they reported that regarding women awareness about LARC, more than half of their participants had heard about LARC in general \& more than half of them believed that LARC methods were safe and effective to prevent the pregnancies for more than 10 years.

In disagreement of these findings, (Crede et al., 2012) who evaluated factors that had an effect on knowledge and initiation of long acting reversible contraceptive methods by postpartum women in South Africa, they found that answer of the participant to the six questions asked to determine their information about the IUD as a LARC methods, more than half of all cases, either did not have 
knowledge or were not sure about effectiveness of IUD in preventing pregnancy for 10 years. The researcher believed that these differences may be due to decrease attention officials in their country.

The present study reported that about two thirds of women in cell phone assisted group attended different settings of family planning clinics (40 days postpartum) \& started to use family planning methods as compared to one third of women in the regular postpartum family planning counselling group. In this respect, (Kirby et al., 2010) who evaluated the effect of phone calls to increase contraceptive uptake through follow-up to women in California, they reported that more than three quarter of respondents told that the calls of phone helped them to use birth control correctly, initiation FP more often and return to follow up on schedule by majority of women. In disagreement with these findings, (Steenland et al., 2013) who assessed the impact of follow-up visits after contraceptive use on continuation of methods, the researchers reported that there was no significant differences between both groups regarding contraceptive use. The researcher believed that these differences may be due to that they owing their results to poor completion rates of phone contact.

According to the present study, One third of the women in the cell phone assisted group had started one of LARC methods compared to only small percentage in control group. Also one third in both groups had used one of short acting methods. In respect of these findings (Shaaban et al., 2013) in their study to assess the effect of using LAM+EC versus using LAM only on the use of FP methods, found that at 6 months postpartum, nearly one third of women in the LAM-EC group used IUD compared to eighteen percent of women in the LAM-only group.

According to the present study findings during the $2^{\text {nd }}$ follow up(6months postpartum) women's attending FP clinic were significantly higher in the cell phone assisted group as compared to control group; nearly three quarter of women in intervention group attended and started using any of family planning methods, one third of them used LARC methods. In disagreement of these findings (Smith et al., 2016) who evaluated the using of a telephone-based (mHealth) intervention to improve initiation of PostAbortion Family Planning (PAFP) in Cambodia, they found that there was no significant difference for interventions to improve contraception use and post abortion family planning (PAFP). In opinion of the researcher these differences may be due to using textmessage, and most of participants unable to read.

According to the present study there were no cases of unplanned pregnancy in the study group compared with 10 cases of unplanned pregnancy in control group with highly statistically significant difference between both groups. In agreement with this finding,(Tawfik et al., 2014) who studied the effect of education about family planning during postpartum care in Afghanistan, they found at 6 months, the difference between the counseling group and control group was significant $(P<0.001)$.

\section{Conclusion}

In the light of the present study findings, it can be concluded that adding cell-phone to the postpartum family planning counseling and service can improve the intake of postpartum women to LARC and the overall contraceptive performance and consequently decrease incidence of unplanned pregnancy.

\section{Recommendations}

Based on the study findings, it was recommended that:

- There is a necessity to create and increase awareness about long acting contraceptive methods.

- Adding phone calls as a reminder to women for improvement uptake of LARC and the overall contraceptive performance.

- Extension of this study is needed for regimented a bigger number of postpartum women to have more clear answer about the role of LARC to reduce unplanned pregnancy.

\section{References}

1. American College of Obstetricians \& Gynecologists. (2012): Adolescents and longacting reversible contraception: implants and intrauterine devices. ACOG Committee Opinion No. 539. American College of Obstetricians Gynecologists. Obstet Gynecol 2012;120:983-8.

2. Alemayehu, M., Belachew, T., \& Tilahun, T., (2012): Factors associated with utilization of long acting and permanent contraceptive methods among married women of reproductive age in mekelle town, tigray region, north ethiopia. BMC Pregnancy Childbirth, 12, 6. doi:10.1186/14712393-12-6

3. Birgisson, N., Zhao, Q., Secura, G., Madden, T., \& Peipert, J., (2015): Preventing unintended pregnancy: The contraceptive choice project in review. J Womens Health (Larchmt), 24(5), 349353. doi:10.1089/jwh.2015.5191

4. Central Agency for Public Mobilization and Statistics. (2013): Statistical Yearbook 2013. Cairo Egypt Central Agency for Public Mobilization and Statistics [Arab Republic of Egypt]. 
5. -Crede, S., Hoke, T., Constant, D., Green, M., Moodley, J., \& Harries, J., (2012): Factors impacting knowledge and use of long acting and permanent contraceptive methods by postpartum hiv positive and negative women in cape town, south africa: A cross-sectional study. BMC Public Health, 12, 197. doi:10.1186/1471-2458-12-197

6. -DaVanzo, J., Hale, L., Razzaque, A., \& Rahman, M., (2007): Effects of Inter Pregnancy Interval and Outcome of the Preceding Pregnancy on Pregnancy Outcomes in Matlab, Bangladesh. BJOG: An International Journal of Obstetrics \& Gynecology, 114, 1079-1087. Accessed at: http://dx.doi.org/10.1111/j.14710528.2007.01338.x

7. -Egypt Demographic and Health Survey (EDHS) (2014)

8. -Heffron, R., Donnell, D., Rees, H., Celum, C., Mugo, N., Were, E., (2012): Use of hormonal contraceptives and risk of hiv-1 transmission: A prospective cohort study. Lancet Infect Dis, 12(1), 19-26. doi:10.1016/s1473-3099(11)70247-X

9. -Kirby, D., Raine, T., Thrush, G., Yuen, C., Sokoloff, A., \& Potter, S., (2010): Impact of an intervention to improve contraceptive use through follow-up phone calls to female adolescent clinic patients. Perspect Sex Reprod Health, 42(4), 251-257. doi:10.1363/4225110.

10. -O'Shea M., Rosenberg N., Hosseinipour M., (2015): Effect of HIV status on fertility desire and knowledge of long-acting reversible contraception of postpartum Malawian women. AIDS Care. 27:489-98.

11. -Shaaban, O., Hassen, S., Nour, S., Kames, M., \& Yones, E., (2013): Emergency contraceptive pills as a backup for lactational amenorrhea method (lam) of contraception: A randomized controlled trial. Contraception, 87(3), 363-369. doi:10.1016/j.contraception.2012.07.013

12. -Smith, C., Vannak, U., Sokhey, L., Ngo, T., Gold, J., \& Free, C., (2016): Mobile technology for improved family planning (motif): The development of a mobile phone-based (mhealth) intervention to support post-abortion family planning (pafp) in cambodia. Reprod Health, 13, 1. doi:10.1186/s12978-015-0112-X

13. -Steenland, M., Zapata, L., Brahmi, D., Marchbanks, P., \& Curtis, K., (2013): The effect of follow-up visits or contacts after contraceptive initiation on method continuation and correct use. Contraception, 87(5), 625-630. doi:10.1016/j.contraception.2012.09.018

14. -Tawfik, Y., Rahimzai, M., Ahmadzai, M., Clark, P., \& Kamgang, E., (2014): Integrating family planning into postpartum care through modern quality improvement: Experience from afghanistan. Glob Health Sci Pract, 2(2), 226233. doi:10.9745/ghsp-d-13-00166

15. Tomlin K., Bambulas T., Sutton M., Pazdernik V., Coonrod D., (2016): Motivational Interviewing to Promote Long-Acting Reversible Contraception in Postpartum Teenagers. Journal of Pediatric and Adolescent Gynecology. 2016 Nov 18;

16. Wilson, E., Samandari, G., Koo, H., \& Tucker, C., (2011): Adolescent mothers' postpartum contraceptive use: A qualitative study. Perspect Sex Reprod Health, 43(4), 230-237. doi:10.1363/4323011

17. Winn-Dix E., Nathan S., Rawstorne P., (2016): Informing the introduction of contraceptive implants in the Pacific: a mixed methods study of contraceptive beliefs and behaviors in Tonga. Australian and New Zealand Journal of Public Health. 2016 Apr; 40(2):115-9. 